V

NCER Working Paper Series

Sportometrics Progam

$=1$ $\left.c^{*} y_{\text {it }}\right)^{2}=$

\title{
The Economics of Discrimination: Evidence from Basketball
}

Lawrence M. Kahn

Working Paper \#40 February 2009

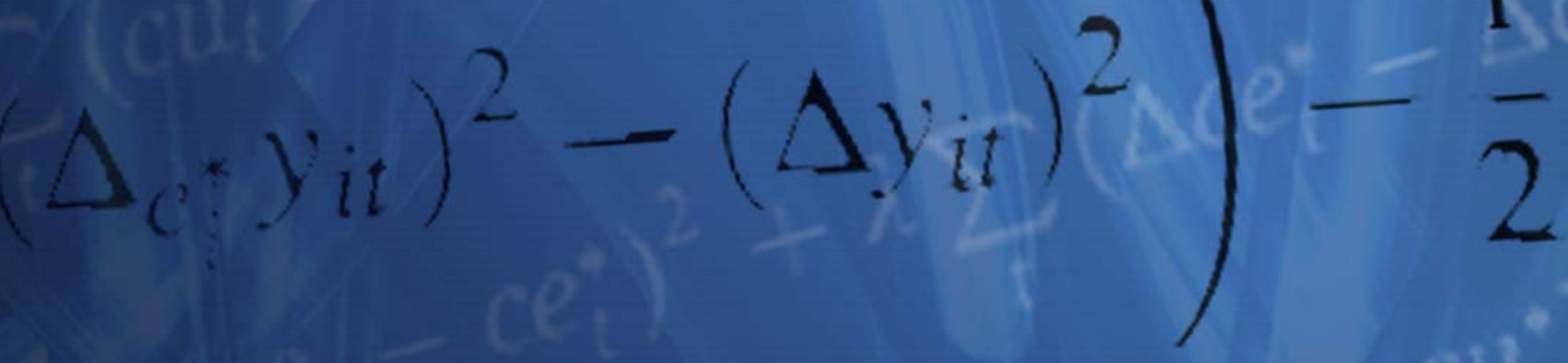




\title{
The Economics of Discrimination: Evidence from Basketball*
}

\author{
by \\ Lawrence M. Kahn \\ Cornell University, CESifo, IZA, and NCER (Australia)
}

January 2009

* This is a draft of a chapter to appear in Stephen Shmanske and Leo Kahane, eds., Oxford Handbook of Sports Economics (New York: Oxford University Press, forthcoming).

Preliminary draft. Comments welcome. Please do not quote without author's permission. 


\title{
The Economics of Discrimination: Evidence from Basketball by
}

\section{Lawrence M. Kahn}

\begin{abstract}
This Chapter reviews evidence on discrimination in basketball, primarily examining studies on race but with some discussion of gender as well. I focus on discrimination in pay, hiring, and retention against black NBA players and coaches and pay disparities by gender among college coaches. There was much evidence for each of these forms of discrimination against black NBA players in the 1980s. However, there appears to be less evidence of racial compensation, hiring and retention discrimination against black players in the 1990s and early 2000s than the 1980s. This apparent decline is consistent with research on customer discrimination in the NBA: in the 1980s, there was abundant evidence of fan preference for white players; however, since the 1980s, these preferences seem much weaker. There appears to be little evidence of pay, hiring or retention discrimination against black NBA coaches, and while male college basketball coaches outearn females, this gap is accounted for by differences in revenues and coaches' work histories. There is some dispute over whether these revenue differences are themselves the result of employer discrimination.
\end{abstract}

Keywords: discrimination, race, gender, basketball. JEL Codes: J71, L83. 


\section{Introduction}

Since the publication of Gary Becker's The Economics of Discrimination (1957), economists have devoted considerable attention to the theory and empirical analysis of labor market discrimination. While a common definition of labor market discrimination would be "unequal treatment of equally qualified workers," it is very difficult to test whether it exists and if so, what its extent is. ${ }^{1}$ This is the case because in most data sets one can use to analyze this question, such as the Census or the Current Population Survey (CPS), our measures of qualifications or productivity are very crude. For example, in the very commonly-used March CPS, the only qualifications-related information we have are a worker's age, type of degree obtained in school (if any), and crude measures of industry and occupation. The CPS doesn't provide any information about workers' performance levels, the quality of their schooling, their work histories, or what employer they work for. Thus, while Census or CPS data can identify race or gender differences in pay for workers with similar measured characteristics, we usually can't make a strong conclusion about the extent of labor market discrimination. In addition, since earnings in such data bases are self-reported, they can suffer from considerable measurement error as well.

In contrast to these deficiencies in the Census or the CPS, the sports business is an excellent setting in which to test theories of labor market discrimination. Unlike the Census or the CPS (or, indeed, longitudinal data such as the Michigan Panel Study of Income Dynamics or the National Longitudinal Surveys), in sports, we have detailed information on each production worker's performance at every time during his/her career. We know exactly what firm each worker is employed by, and we also have information on the identity and performance of each athlete's co-workers (teammates) and immediate

\footnotetext{
1 There are of course other potential forms of discrimination such as discrimination in access to qualifications or differential standards for hiring, promotion, or retention. I will explore evidence on these in the context of basketball, as well as the more familiar form of discrimination, unequal treatment of equally qualified workers.
} 
supervisor (i. e. the coach or manager). In many cases, we have detailed information about each player's compensation package (contract), often supplied by the league or a players' association. These administrative sources of compensation data are likely to be more accurate than self-reports of earnings and have the advantage that they "often contain the actual information used to make economic decisions" (Angrist and Krueger 1999, p. 1338). In professional sports settings, we know how each player was selected for employment, and in many cases we also know the circumstances surrounding a player's exit from the team, allowing for a study of hiring and retention discrimination.

In this Chapter, I review evidence on the extent of discrimination in basketball. This is an especially interesting sport in which to study racial discrimination, for several reasons. ${ }^{2}$ The National Basketball Association (NBA) is seen by many as an oasis of economic opportunity for highly skilled African-American athletes. Roughly $80 \%$ of the league's players are black. Of the 42 players who as of the 2001-2 season had signed contracts with annual salaries of more than $\$ 10$ million (the top decile of the league's 415 players), fully 37 (88\%) were black (these figures are taken from data used in Kahn and Shah 2005). Of the 50 players who had ever been on an NBA allstar team before signing their current contracts (as of the 2001-2 season), only four were white. Black success has even progressed to the coaching ranks, where as of the beginning of the 2008-9 season, 11 of the NBA's 30 coaches were black (www.espn.com, accessed October 14, 2008), representing a higher percentage than in football or baseball. ${ }^{3}$

Despite this clear evidence of black success in the NBA, the question of discrimination against African Americans remains a salient one. It has been reported, for example, that black players look with suspicion at specific, marginal white players' generous contracts as possible evidence of discrimination (Platt 2000). The 1998 NBA

\footnotetext{
${ }^{2}$ While most of my review will center on race, I will also discuss some evidence on discrimination against female college basketball coaches.

3 For example, in Major League Baseball in 2008, only 7 of 30 managers were black or Hispanic, and in the NFL, only 6 of 32 coaches in 2008 were black (www.espn.com, and www.nfl.com, both accessed October 14, 2008).
} 
lockout, involving a league of white team owners and an $80 \%$ black union, was seen by many players as a racial confrontation (Shropshire 2000). And sports league

punishments imposed on players who commit acts of violence are seen by some as biased against black players (Shropshire 2000). Whether these perceptions are accurate in the individual cases involved, and whether, assuming they are accurate, they represent the pattern and practice of the NBA, the fact that they are held at all is reason enough to explore the issue of race in the NBA, in addition to the econometric advantages of sports data.

This Chapter reviews evidence on discrimination in basketball. I first discuss the economics of discrimination, focusing on Becker's (1957) analysis of the possible sources of discrimination in labor markets (firms, co-workers and customers). A key feature of this discussion will be the persistence of various types of discrimination in competitive labor markets. Any of these sources can lead to various manifestations of discrimination, including pay, access to jobs, and susceptibility to layoff or discharge. I then review evidence on each of these possible forms of discrimination in basketball, including both a discussion of methodological issues as well as substantive findings. While there are a variety of results in the literature, in general, racial discrimination in professional basketball seemed more prevalent in the 1980s than is the case today.

\section{The Economics of Discrimination: Theoretical Considerations}

Gary Becker (1957), in his seminal work on the economics of discrimination, identified three forms of discrimination: employer, coworker (including supervisors and supervisees as well as lateral coworkers), and customer. With constant returns to scale, free entry, and the existence of some profit maximizing firms, discriminating employers will be driven out of business by the nondiscriminator(s), and coworker discrimination 
will lead to equally competitive segregated firms with equal pay for equal work. However, customer discrimination is different from these forms of prejudice, because an employer that pays more money to the types of workers whom customers prefer is likely to be rewarded by the market. Conversely, those workers who are not preferred by customers, but have a personal comparative advantage in the affected job, will either need to accept lower pay, if they remain in the customer sector, or else move to the noncustomer sector, where their comparative advantage is lost (Kahn 1991a). This argument suggests that competitive forces are less likely to eliminate customer-based discrimination than that based on employer or coworker prejudice. With heterogeneous consumer preferences, we may observe segregation and equal wages, if consumers have equal income and access to capital. Thus, the persistence of wage differences based on customer discrimination will be an empirical question. Of course, the sports industry is a customer-based service sector. Further, sports leagues as monopolies may not face the kind of free entry that might serve to discipline discriminating employers.

If most employers have a taste for discrimination, then a nondiscriminating employer can either win more games, or reduce expenses, or both, by hiring the most productive workers at the lowest cost possible. While this argument has been tested formally and upheld in the context of Major League Baseball's integration (Gwartney and Haworth, 1974; Hanssen, 1998), it has not been tested in the context of basketball. However, the Boston Celtics' early dominance and its early deployment of many black stars in the late 1950s and early 1960s such as Bill Russell, Sam Jones, K.C. Jones, and Tom Sanders may be considered anecdotal evidence for this view.

As noted, black players today comprise about $80 \%$ of NBA rosters, so the type of co-worker prejudice and demands by some white players to be traded rather than have black teammates, as in the early days of baseball integration (Kahn 1991b), may not be so relevant to today's NBA. However, the effects of customer prejudice can be felt even if owners and white players are not prejudiced. Suppose, for example, that fans prefer to 
see white players, and also suppose that a black and a white NBA player of equal ability each become free agents at the same time. If fans are prejudiced, the white player is more likely to have large fan club and a highly-rated television or radio show in his current locality than an equally-accomplished black player. The white player's agent is likely to present this information to alternative teams in negotiating for a new contract. Even if the teams aren't thinking about the player's race, they will be thinking about the player's ability to draw fans. Under these circumstances, we expect the white player to obtain a better offer than the black player.

As I will discuss in more detail below, players with less than roughly 3-4 years of NBA experience are not allowed to be free agents (at least until they are released by their current team) and must either deal with the team that owns their contract or leave the industry. Thus these players are subject to the monopsony power of their team. If black and white players have different labor supply elasticities to the team, then we would expect unequal wages for equally qualified black and white players. This reasoning has been used by Robinson (1969) and Madden (1973) to explain sex differences in pay (on the assumption that women have lower labor supply elasticities to the firm than men do), and, more relevant to the current review, by McCormick and Tollison's (2001) to explain the black salary shortfall in the NBA in the 1980s. Along the same lines, in a Nash bargain, the player with lower status quo income will end up with the lower salary level (Binmore, Rubinstein and Wolinsky 1986). Thus, if black non-free agents have lower family incomes than whites do (as is likely), then these bargaining considerations could also lead to lower salary levels for black than white players of equal ability (Kahn and Shah 2005). Free agents, in contrast, are expected to receive their market value, which may of course include the impact of customer prejudice (as would the salaries of the nonfree agents through the Nash bargaining process). 


\section{Research on Salary Discrimination in Basketball}

Most studies of salary discrimination in basketball analyzing NBA players use as a basic empirical model the following type of wage regression referring to a given season:

(1) $\ln$ Salary $_{i}=$ B $^{\prime} \mathrm{X}_{\mathrm{i}}+\mathrm{a}^{*} \mathrm{WHITE}_{\mathrm{i}}+\mathrm{u}_{\mathrm{i}}$

where for each player $\mathrm{i}$, Salary is the annual salary, $\mathrm{X}$ is a vector of player and team characteristics to be discussed below, WHITE is a dummy variable for white players, and $\mathrm{u}$ is a disturbance summarizing unmeasured influences on salary.

The dependent variable in most studies is the current year's salary, although in many cases, players (or coaches) sign long term guaranteed contracts which include signing bonuses and deferred payments. An accurate accounting of compensation should take into account these non-salary payments. Even so, it is not obvious what the dependent variable should be. On the one hand, we would like a measure of the price of labor, and the player's annual compensation (including the annualized bonuses and deferred payments) fits this bill. On the other hand, for many players, a three year $\$ 18$ million contract does not yield the same utility as a one year \$6 million contract, for instance, even though the annual price of labor is the same. It is therefore also possible that using as an additional dependent variable the total compensation guaranteed in the contract yields additional information beyond a model using only average annual compensation. In addition, it is important to know when a player signed his current contract in order to collect information about his playing record or negotiation rights that was known as of the signing. For example, a player during the 2007-8 season may have signed his contract, for example, in 2003, when he wasn't a free agent, even if under the rules, he would have been eligible for free agency had he negotiated in 2007. These 
issues are explored in Kahn and Shah's (2005) study of NBA players and Kahn's (2006) analysis of NBA coaches.

The list of control variables $\mathrm{X}$ usually contains player performance variables such as scoring, rebounding, steals, and blocked shots, as well as NBA experience, where one was drafted (if drafted), NBA awards and allstar team participation, and team and market factors. These market factors can include the income and population levels of the team's location as well as its racial composition. While these variables are straightforward to interpret, as noted earlier, they comprise a much more comprehensive list of performance and qualifications measures than we can obtain from sources such as the Census or the CPS. For example, the 2008 CPS uses the 2002 Census Codes for industry and occupation. In the CPS, an NBA first round draft pick who, say, attended one year of college, would be observationally equivalent to a player of the same race and age who dropped out of college after one year, was not drafted and is currently playing minor league basketball in a venue such as the NBA Developmental League. ${ }^{4}$

The explanatory variable of most interest in equation (1) for analyzing discrimination is the race indicator (WHITE). The equation forces the ceteris paribus racial pay differential to be the same regardless of performance level, although some authors have investigated whether there are interaction effects between a player's race and some explanatory variables such as playing experience (Kahn and Sherer 1988) or the racial makeup of the community (Kahn and Sherer 1988; Bodvarsson and Partridge 2001; Kahn and Shah 2005).

While we are tempted to conclude that the coefficient on WHITE is an estimate of the extent of discrimination against black players, we still need to be cautious in this

\footnotetext{
${ }^{4}$ They would both be in the same detailed industry (Census Code 8560: "Independent artists, performing arts, spectator sports, and related industries") and the same detailed occupation (Census Code 2720: "Athletes, coaches, umpires, and related workers"). See www.nber.org for this documentation. Pursuing the comparison between the CPS and NBA data, note that the 2008 March CPS earnings data are topcoded at $\$ 200,000$, while the minimum NBA salary for the 2008-9 season is $\$ 442,114$ (see the 2005 NBA Collective Bargaining Agreement at www.nbpa.com). Thus, everyone on at least an annual NBA contract would be topcoded in the CPS.
} 
regard, although as mentioned, the set of controls here is much more extensive than in other non-sport settings. First, the race variable may be correlated with unmeasured factors such as teamwork that affect productivity and pay, even controlling for the $\mathrm{X}$ variables. The direction of such correlations is uncertain; if black players have higher levels of unmeasured productivity, then the WHITE coefficient will understate the extent of salary discrimination, while if white players are more productive in ways we can't measure, then the opposite will be true. Below I will present some suggestive evidence on this question. Second, some of the explanatory variables may themselves be the result of discrimination, implying that the WHITE coefficient may understate the full effects of discrimination on pay. For example, if coaches give white players more playing time (possibly in response to fan preferences), then they will have better performance statistics. In addition, it has recently been suggested that on average, referees may make calls more favorable to white players, again inflating their performance statistics (Price and Wolfers 2007).

With these preliminaries in mind, let us turn to the evidence on wage discrimination in basketball. Table 1 summarizes results from several studies of race and NBA salaries (players or coaches) and one of gender and college basketball coaches' salaries. ${ }^{5}$ Using data from the mid-1980s, several authors found apparently discriminatory wage differentials favoring white players in the NBA. Controlling for a variety of performance and market-related statistics, there were statistically significant black salary shortfalls of 11-25\%, depending on sample and specification (Kahn and Sherer 1988; Koch and Vander Hill 1988; Wallace 1988; and Brown, Spiro, and Keenan 1991). The apparent discrimination was especially noteworthy since for the 1985-6 season, black players on average earned $\$ 407,000$, while whites earned $\$ 397,000$;

\footnotetext{
5 Of the studies of NBA players, Table 1 only includes those using data from 1984 onward and covering most or all players. There were a number of earlier studies using small samples (28 and less) from 19701981, and these are summarized in Kahn (1991b).
} 
however, controlling for performance and market related variables, the ceteris paribus white effect was 21-25\% and was highly statistically significant (Kahn and Sherer 1988). This combination of results shows how important it can be to control for productivity, which in this case was higher for black players, in assessing the extent of discrimination.

As noted earlier, there may still be omitted variables that could have explained the ceteris paribus white salary advantage; however, reverse regression tests can under some restricted circumstances take account of such problems (Goldberger 1984). These tests involve using the productivity factors as dependent variables in regressions with log salary as the explanatory variable. In the 1985-6 NBA data, they showed even larger apparent discrimination coefficients against black players than the usual direct regression of log salary on X and WHITE did (Kahn and Sherer 1988). These tests therefore imply that black players in the mid 1980s had better unmeasured productivity characteristics than white players with the same X's. This may not be surprising, since black players had more favorable measured productivity as well.

By the 1990s, there appeared to be much less evidence of salary discrimination against black NBA players. Table 1 shows that studies of the 1990-91 (Bodvarsson and Brastow 1998), 1994-5 (Hamilton 1997), 1987-93 (Dey 1997), and 1996-7 (Gius and Johnson 1998) seasons all showed no significant racial salary differentials on average, all else equal. Moreover, Eschker, Perez and Piegler (2004) found insignificant racial salary gaps in 5 of 6 seasons between 1996 and 2002, with only 1998-99 showing a significant white premium (14-20\%). However, Hamilton (1997) did find evidence of unexplained black salary shortfalls only among the elite players in the NBA. To examine discrimination across the distribution of playing talent, he used quantile regressions and found no significant racial salary differentials at the $10^{\text {th }}, 25^{\text {th }}$, and $50^{\text {th }}$ percentiles but positive and significant (at the 5.6\% and $12 \%$ levels on two-tailed tests) white pay effects 
at the $75^{\text {th }}$ and $90^{\text {th }}$ percentiles amounting to 0.18 to $0.19 \log$ points. ${ }^{6}$ These results suggest that while there was no significant unexplained black salary shortfall on average in the NBA in the $1994-5$ season, for star players (i.e. those at the $75^{\text {th }}$ percentile and above in the conditional wage distribution), there may have been substantial discrimination in favor of whites.

A recent study of the 2001-02 NBA season found that for the league as a whole, there were small to moderate and generally statistically insignificant annual salary differentials favoring white players, all else equal (Kahn and Shah 2005). However, there were larger and usually statistically significant racial differentials in total compensation favoring white players, and whites overall also had statistically significantly longer contract duration (Table 1). An important feature of this study was its disaggregation of the sample into three groups according to their negotiation rights: a) veterans with less than three years of service, plus rookies not drafted on the first round, as well as rookies who entered the NBA before 1995, when a rookie salary scale was put in place-players who are not free agents and are subject to their individual teams' monopsony power; b) first round draft picks whose salary is set in the collective bargaining agreement; and c) free agents (who need to have at least 3-4 years of NBA experience). The authors found large, statistically significant racial effects favoring whites in annual salary (.30-.50 log points), total contractwide compensation (.7-.9 log points), and contract duration (1.3-1.5 more years of guaranteed money) only among group a)--players subject to individual teams' monopsony power. But for the other groups-players under the rookie salary scale, as well as veteran free agents, there were only very small and statistically insignificant racial effects for each of these dependent variables. Thus, the results appear to support the discriminating monopsony model (McCormick and Tollison 2001) or models of Nash bargaining where black players have lower status quo income than

\footnotetext{
${ }^{6}$ The effect on log salary of being white for the lower percentiles was: -.184 (asymptotic standard error .291 ) for the $10^{\text {th }}$ percentile, $-.209(.183)$ for the $25^{\text {th }}$ percentile, and $-.005(.152)$ for the $50^{\text {th }}$ percentile.
} 
whites. For group b)—players on the rookie salary scale-- salary is exogenous once we know when one was drafted, and for group c) — free agents, the market is competitive, so the discriminating monopsony/Nash bilateral monopoly model is less relevant for them.

It is interesting to note that in Kahn and Shah's (2005) study, there were two situations in which racial pay differentials for similarly qualified players were absent: i) players under the rookie salary scale; ii) free agents. The rookie salary schedule is a union pay scale, and the absence of racial salary differences once one controls for draft position is analogous to the small racial pay differences one would expect to observe under union standard rate schemes (Ashenfelter 1972; Freeman 1982). The nonwhite free agents are protected by employer competition, at least in the seeming absence of customer discrimination (as also found by Kahn and Shah 2005), as predicted by Becker's (1957) model of discrimination. Thus, union pay scales and competition are both potential mechanisms that can reduce racial pay differences.

As noted earlier, these studies of race and pay in basketball may understate discrimination if some of the explanatory variables are themselves caused by discrimination. In a recent study, Price and Wolfers (2007) have found evidence consistent with this outcome. Specifically, the authors studied NBA games between 1991 and 2004 and found that players were assessed by as many as $4 \%$ fewer fouls and scored $2 \frac{1}{2} \%$ more points during games in which their race matched that of the refereeing crew. The study was notable for the extensive list of controls including player fixed effects, referee fixed effects, and game fixed effects. Since most referees are white, this matching effect is more likely to benefit white players than black players. The authors' results imply that replacing an all-white refereeing crew with an all-black crew will raise black players' scoring average by about $2.5 \%$, or by 0.26 points per game among experienced black players in the 2001-2 season, according to data used by Kahn and Shah (2005). Using these data for the 2001-2 season, one finds that among experienced players, raising one's points per game scoring average by one point leads to a statistically 
significant $0.056 \log$ point salary increase, controlling for experience, rebounding, assists, blocked shots, race, position and market characteristics. Thus, replacing all-white refereeing crews by all-black crews would raise an individual black player's salary by $0.015 \log$ points (i.e. 0.26 more points per game times $0.056 \log$ points of salary); an individual white player's salary would be lowered also by $0.015 \log$ points. ${ }^{7}$ The refereeing crews during Price and Wolfers' (2007) sample period were 68\% white, in contrast to the $20 \%$ white representation among players. If refereeing crews' racial composition were the same as that of the players, then white representation among referees would decline by 48 percentage points. We would therefore predict a rise in black player salaries due to scoring by $0.007 \log$ points, and an equal fall in white player salaries. Therefore, average white relative salaries would fall by 1.4 percentage points, a modest change. Of course, other aspects of playing such as playing time and style may also be affected by refereeing. But overall, biased refereeing does not appear to responsible for a large decline in black players' relative pay.

All of the studies of salary discrimination mentioned so far have focused on race and NBA players. There have been two studies of discrimination in coaches' salaries. First, Kahn (2006) found that from 1997-2004, there were small and statistically insignificant salary racial salary differentials, all else equal, between white and black NBA head coaches. Second, Humphreys (2000) studied male and female college basketball coaches for the 1990-91 season. While on average, men earned more than women, this difference disappeared once the author controlled for revenues, whether the team was a women's or a men's team, type of school, and the coach's experience and performance. Thus, Humphreys (2000) did not find evidence of unequal pay for equal work. However, as discussed above, some of the controls themselves may be subject to discrimination, implying that the regressions may have understated the extent of salary

\footnotetext{
${ }^{7}$ While the overall effect on average salary levels of such a change in the composition of referees cannot be determined, the logic of this example implies that black relative salaries would rise by $0.03 \log$ points.
} 
discrimination. A Federal sex discrimination suit filed by the female former coach of the University of Southern California women's basketball team made precisely this allegation (Stanley v. USC, 9th Circuit Court of Appeals, 1999). ${ }^{8}$ The program paid the male men's coach more than the women's coach, partly on the grounds that the men's program brought in more revenue than the women's program. The plaintiff had argued that the men's team revenues were higher than the women's team revenues due to discriminatory access to marketing resources. In the end, the Appeals Court did not need to rule on the question of whether the higher men's team revenues were tainted by discrimination. Rather, the Court noted that the men's coach had more experience and a more successful coaching career than the women's coach; in addition, the Court noted that, unlike the women's coach, the men's coach was a recognized authority on basketball coaching, as shown by noting the books he had authored. Therefore, the issue of whether a gender difference in revenue produced is a legitimate factor upon which to base a gender difference in coaching salaries is an open question from the legal point of view.

\section{Research on Discrimination in Hiring and Retention in Basketball}

Even if there were equal pay for equal work in basketball, it is still possible that black players (or coaches) face barriers to entry or lower probabilities of being retained than equally performing white players (or coaches). Several studies have examined these issues in basketball (Table 2). Straightforward analyses of entry barriers for players include studies of the player draft, where the determinants of where one was drafted are estimated as a function of college (if any) performance and race. Analyses of the 198586, (Kahn and Sherer 1988), 1987-92 (Dey 1997), 2001-02 (Kahn and Shah 2005) all fail

\footnotetext{
${ }^{8}$ The Appeals Court decision can be found at: http://laws.findlaw.com/9th/9555466.html.
} 
to find racial effects on draft position, all else equal. There thus doesn't appear to be direct entry discrimination into the NBA on the basis of race, although it is still possible that there are racial barriers to entry into college basketball. In particular, college entrance exam requirements by the NCAA may have racially disparate effects on entry, given the likely racial gap in the quality of high schools. These studies of the draft also don't estimate the probability of being drafted in the first place, presumably because such an analysis would require data on all college and high school players eligible for the draft.

An alternative take on the question of entry discrimination is to compare the performance of black and white incumbents, as some authors have done. The idea behind such analyses is that if, for example, black players or coaches face racial entry barriers, then the performance of black incumbents should be greater than that of white incumbents. The most valid of these studies focus on performance differences of marginal, rather than average, incumbents, as the following two examples will illustrate. In both cases, suppose that there are two black and two white players and that we can measure their quality on a cardinal scale. In the first case, let the two white players have quality levels of $q$ and $2 q(q>0)$, and let the two black players have quality levels of $q$ and 3q. And let $\mathrm{q}$ be the minimum league standard for hiring a player, which in this example is the same for black and white candidates. In this case, the average white player will have quality $1.5 \mathrm{q}$, and the average black player quality is $2.0 \mathrm{q}$. Using average performance differentials would suggest hiring discrimination against black players. However, such a conclusion would be incorrect if $\mathrm{q}$ is the minimum hiring standard of quality the league accepts regardless of race, as assumed in this example. At the margin, where the hiring decision is made, whites and blacks are equally qualified in this example. ${ }^{9}$

\footnotetext{
${ }^{9}$ This point about the conceptual difficulties in using racial differences in average performance levels as an indicator of discrimination in hiring was first made in the sports context in Pascal and Rapping's (1972)
} 
In the second example, let the white players' quality be $\mathrm{q}$ and $3 \mathrm{q}$ and the black players' quality be $2 \mathrm{q}$ and $2 \mathrm{q}$. In this case, black and white players have the same average quality, and an analysis based on average quality will conclude that there is no hiring discrimination. However, if the minimum quality white and black players are both at the margin of entry, then the league in this case has a tougher standard for black than for white candidates. Thus, in this example, focusing on average quality or performance may cause us to incorrectly conclude that there is no hiring discrimination. In both of these examples, focusing on the marginal players allows us to make the correct inference.

Table 2 shows the results of two analyses of racial differences in the performance of marginal workers. First, Brown, Spiro and Keenan (1991) found that there were few performance differentials between black and white benchwarmers in the NBA during 1984-85, suggesting the absence of hiring discrimination. Interestingly, for the average player, blacks generally outperformed whites, a finding that might have led one to erroneously conclude that there was entry discrimination against black players. Second, Kahn (2006) found that among NBA coaches who were at the margin of being in the league, there were no statistically significant racial performance differences. He used quantile regressions of winning percentage, focusing on the $10^{\text {th }}$ percentile of the conditional distribution as an indicator of being at the margin.

An additional form of quantity-based discrimination is differential treatment with respect to layoffs or discharges. Two studies of exit discrimination against black NBA players come to opposite conclusions. On the one hand, using a hazard function analysis, Hoang and Rascher (1999) found that during the 1980-91 period, white players had a $36 \%$ lower risk of being cut than comparable black players, an effect that was marginally significant. On the other hand, also using a hazard function approach, Groothuis and Hill (2004) found no evidence of exit discrimination during the 1989-99 period. ${ }^{10}$ Moreover,

${ }^{10}$ Since pro basketball is likely to be players' best earnings opportunity by far, it is reasonable to suppose 
for the 1997-2003 period, Kahn (2006) found no racial differences among NBA coaches' quit, discharge, or overall exit (i.e., quits and discharges aggregated) hazards, all else equal. These latter two studies suggest the absence of retention discrimination against either black players or coaches in the 1990s and early 2000s.

\section{Research on Customer Discrimination in Basketball}

The previous two sections have found some evidence, especially for the 1980s, of both salary and retention discrimination against black players in the NBA. By the 1990s, there much less evidence of these kinds of discrimination. As discussed earlier, when there is customer discrimination, free entry and profit maximization may not eliminate or even reduce discriminatory differentials in employment outcomes. In fact, markets will generally reward firms that bestow higher rewards on the kinds of workers their customers want to be served by. Accordingly, I now review evidence on the extent of customer discrimination in basketball.

Table 3 summarizes results of a variety of studies of customer discrimination in basketball. And there is indeed evidence from the 1980s consistent with the existence of such preferences. For example, Kahn and Sherer (1988) found that, all else equal, during the $1980-86$ period each white player generated 5,700 to 13,000 additional fans per year. The dollar value of this extra attendance more than made up for the white salary premium they found (see Table 1). Hoang and Rascher (1999) also examined NBA attendance during the 1980-91 period and found that, other things equal, larger values of (percent white on the team/percent white in the city) were significantly positively associated with attendance. This finding is consistent with the idea of customer preferences for white players. Consistent with these studies of NBA attendance, Brown and Jewell (1994)

that most exits from the league are due to injury or being cut, rather than due to locating a better job in another sector. 
found that, all else equal, a higher share of white players raised college basketball programs' revenues during the 1988-89 season: on average, a white player generated slightly over $\$ 100,000$ more annual gate revenue than an identically productive black player.

Further evidence on customer discrimination during this period comes from studies that found a close match between the racial makeup of NBA teams in the 1980s and of the areas where they were located, again suggesting the importance of customer preferences (Brown, Spiro and Keenan 1991; Burdekin and Idson 1991; Hoang and Rascher 1999; Bodvarsson and Partridge 2001). I note that player preferences could also have produced a similar result, if black players, for example, prefer to play in areas with a larger relative black population. In this regard, Bodvarsson and Partridge (2001) found that black population share interacted with team black share had significantly positive effects on black salaries in 1985-6 and 1990-1, although the authors point out that team racial composition is likely to be endogenous. But if this result is indeed causal, it does suggest customer discrimination, since in its absence we would expect black players to make less in the areas they want to live in (through the usual compensating differentials mechanism).

While most of the evidence from the 1980s does suggest the existence of customer preferences for white players, McCormick and Tollison (2001) found no overall statistical relationship between team racial composition and home attendance for the 1980-87 period, although among the quartile of metropolitan area locations with the largest black population shares, more white players actually reduced attendance, all else equal. And Brown, Spiro and Keenan (1991) found that the percent of black playing time in the NBA did not affect attendance in the 1983-84 season.

The evidence for customer discrimination in the NBA in the1990s and 2000s seems weaker than it was during the 1980s. Dey (1997), for example, found that all else equal, white players added a statistically insignificant and economically relatively 
unimportant 60 fans apiece per season during the 1987-93 period. Moreover, Stone and Warren (1999) studied 1993 basketball trading card prices, an indicator of fan preferences, and found no racial differences in prices, controlling for player performance. Kahn and Shah (2005) found no evidence of any impact of team racial composition on fan attendance in the NBA during the 1996-2001 seasons. And Coleman, DuMond and Lynch (2008) found no evidence of racial discrimination in NBA Most Valuable Player voting by writers and sportscasters during the 1995-2005 period. On the other hand, Kanazawa and Funk (2001) found that, other things equal, more white players had a significantly positive effect on Nielsen ratings of televised NBA games during the 1996-7 season. And Burdekin, Hossfeld and Smith (2005) found for the 1990-99 NBA seasons that the closeness of the racial match between the team and its metropolitan area raised attendance. This comparison of the evidence on customer discrimination in basketball during the 1980 s vs. the post-1980s period decades is consistent with the evidence consistent with a decline in salary and retention discrimination in the NBA during this period.

\section{Conclusions}

In this Chapter, I have reviewed evidence on salary, hiring and retention, and customer discrimination in basketball. There was much evidence for each of these forms of discrimination against black NBA players in the 1980s. However, there appears to be less evidence of racial compensation, hiring and retention discrimination in the 1990s and early 2000s than the 1980s, and the apparent decline in customer discrimination since the 1980 s is consistent with these changes. It is interesting to note that analyses of racial pay gaps in football and baseball generally do not find large or statistically significant

nonwhite salary shortfalls, ceteris paribus (Kahn 2000). It is perhaps noteworthy that the sport with the most evidence consistent with racial salary discrimination, basketball, has 
historically had the largest black representation: as of the mid 1990s, it was 80\%, in contrast to baseball's $30 \%$ and football's $65 \%{ }^{11}$ These differences in racial representation suggest that customer preferences may have something to do with the racial pay gap we observed in basketball in the 1980s.

${ }^{11}$ These figures were very similar in the 1980s as well. See Kahn (1991b) and Staudohar (1996). 


\section{References}

Angrist, J. D, and Krueger, A. B. 1999. 'Empirical Strategies in Labor Economics', in O. Ashenfelter and D. Card (eds.), Handbook of Labor Economics, vol. IIIA. Amsterdam: North-Holland, 1277-1366.

Ashenfelter, O. 1972. 'Racial Discrimination and Trade Unionism.' Journal of Political Economy, 80(3): 435-464.

Becker, G. S. 1957. The Economics of Discrimination. Chicago: University of Chicago Press.

Binmore, K., Rubinstein, A., and Wolinsky, A. 1986. 'The Nash Bargaining Solution in Economic Modelling'. Rand Journal of Economics, 17(2): 176-188.

Bodvarsson, Ö., and Brastow, R. T. 1998. 'Do Employers Pay for Consistent Performance? Evidence from the NBA.' Economic Inquiry, 36(1): 145-160.

Bodvarsson, Ö., and Partridge, M. D. 2001. 'A Supply and Demand Model of CoWorker, Employer and Customer Discrimination.' Labour Economics, 8(2): 389416.

Brown, E., Spiro, R., and Keenan, D. 1991. 'Wage and Nonwage Discrimination in Professional Basketball: Do Fans Affect It?' American Journal of Economics and Sociology, 50(3): 333-45.

Brown, R. W., and Jewell, R. T. 1994. 'Is There Customer Discrimination in College Basketball? The Premium Fans Pay for White Players.' Social Science Quarterly, 75(2): 401-413.

Burdekin, R. C. K., Hossfeld, R. T., and Smith, J. K. 2005. 'Are NBA Fans Becoming Indifferent to Race?' Journal of Sports Economics, 6(2): 144-159.

Burdekin, R. C. K., and Idson, T. L. 1991. 'Customer Preferences, Attendance and the Racial Structure of Professional Basketball Teams.' Applied Economics, 23(1), Part B: $179-86$.

Coleman, B. J., DuMond, J. M., and Lynch, A. K. 2008. 'An Examination of NBA MVP Voting Behavior: Does Race Matter?' Journal of Sports Economics, 9(6): 606-627.

Dey, M. S. 1997. 'Racial Differences in National Basketball Association Players' Salaries: Another Look.' The American Economist, 41(2): 84-90.

Eschker, E., Perez, S. J., and Siegler, M. V. 2004. 'The NBA and the Influx of International Players.' Applied Economics, 6(10): 1009-1020.

Freeman, R. B. 1982. 'Union Wage Practices and Wage Dispersion within Establishments.' Industrial \& Labor Relations Review, 36(1): 3-21.

Goldberger, A. S. 1984 'Reverse Regression and Salary Discrimination.' Journal of Human Resources, 19(3): 293-318. 
Gius, M., and Johnson, D. 1998. 'An Empirical Investigation of Wage Discrimination in Professional Basketball.’ Applied Economics Letters, 5(11): 703-705.

Groothuis, P. A., and Hill, J. R. 2004. 'Exit Discrimination in the NBA: A Duration of Analysis of Career Length.' Economic Inquiry, 42(2): 341-349.

Gwartney, J., and Haworth, C. 1974. 'Employer Costs and Discrimination: The Case of Baseball.' Journal of Political Economy, 82(4): 873-881.

Hamilton, B. H. 1997. 'Racial Discrimination and Professional Basketball Salaries in the 1990s.' Applied Economics, 29(3): 287-96.

Hanssen, A. 1998. 'The Cost of Discrimination: A Study of Major League Baseball." Southern Economic Journal, 64(3): 603-627.

Hoang, H., and Rascher, D. 1999. 'The NBA, Exit Discrimination, and Career Earnings.' Industrial Relations, 38(1): 69-91.

Humphreys. B. R. 2000. 'Equal Pay on the Hardwood: The Earnings Gap Between Male and Female NCAA Division I Basketball Coaches.' Journal of Sports Economics, 1(3): 299-307.

Kahn, L. M. 1991a. 'Customer Discrimination and Affirmative Action.' Economic Inquiry, 29(3): 555-571.

Kahn, L. M. 1991b. "Discrimination in Professional Sports: A Survey of the Literature," Industrial \& Labor Relations Review. 44:3 (April), pp. 395-418.

Kahn, L. M. 2000. 'The Sports Business as a Labor Market Laboratory.' Journal of Economic Perspectives, 14(3): 75-94.

Kahn, L. M. 2006. 'Race, Performance, Pay, and Retention Among National Basketball Association Head Coaches.' Journal of Sports Economics, 7(2): 119-149.

Kahn, L. M., and Sherer, P.D. 1988. 'Racial Differences in Professional Basketball Players' Compensation.' Journal of Labor Economics, 6(1): 40-61.

Kahn, L. M. and Shah, M. 2005. 'Race, Compensation and Contract Length in the NBA: 2001-2002.' Industrial Relations, 44(3): 444-462.

Kanazawa, M. T., and Funk, J. P. 2001. 'Racial Discrimination in Professional Basketball: Evidence from Nielsen Ratings.' Economic Inquiry, 39(4): 599-608.

Koch, J. V., and Vander Hill, C. W. 1988. 'Is There Discrimination in the "Black Man's Game”?' Social Science Quarterly, 69(1): 83-94.

Madden, J. F. 1973. The Economics of Sex Discrimination. Lexington, MA: Lexington Books.

McCormick, R. E., and Tollison, R. D. 2001. 'Why Do Black Basketball Players Work More for Less Money?' Journal of Economic Behavior \& Organization, 44(2): 201-219.

NBA Collective Bargaining Agreement 2005. 
Pascal, A. H., and Rapping, L. A. 1972. 'The Economics of Racial Discrimination in Organized Baseball', in A. H. Pascal (ed.), Racial Discrimination in Economic Life. Lexington, MA.: DC Heath, 1972, 119-156.

Platt, L. 2000. 'The White Shadow', in T. Boyd and K. L. Shropshire (eds.), Basketball Jones. New York: New York University Press, 68-74.

Price, J., and Wolfers, J. 2007. 'Racial Discrimination Among NBA Referees.' National Bureau of Economic Research Working Paper 13206. Cambridge, MA: National Bureau of Economic Research.

Robinson, J. 1969. The Economics of Imperfect Competition, $2^{\text {nd }}$ Edition. London: Macmillan.

Shropshire, K. L. 2000. 'Deconstructing the NBA', in T. Boyd and K. L. Shropshire (eds.), Basketball Jones. New York: New York University Press, 75-89.

Staudohar, P. D. 1996. Playing for Dollars: Labor Relations and the Sports Business. Ithaca, NY: Cornell University Press.

Stone, E. W., and Warren, Jr., R.S. 1999. 'Customer Discrimination in Professional Basketball: Evidence from the Trading-Card Market.' Applied Economics, 31(6): 679-685.

Wallace, M. 1988. 'Labor Market Structure and Salary Determination Among Professional Basketball Players.' Work and Occupations, 15(3): pp. 294-312. 


\begin{tabular}{|c|c|c|}
\hline Study & Setting & Results \\
\hline Kahn and Sherer (1988) & NBA players $1985-86$ & $\begin{array}{l}21-25 \% \text { salary premium for white players, statistically } \\
\text { significant (1\%). }\end{array}$ \\
\hline Koch and Vander Hill (1988) & NBA players $1984-85$ & $\begin{array}{l}12 \% \text { premium for white players, statistically significant } \\
(10 \%) .\end{array}$ \\
\hline Wallace (1988) & NBA players $1984-85$ & $\begin{array}{l}18 \% \text { premium for white players, significant significant } \\
(10 \%) .\end{array}$ \\
\hline Brown, Spiro, and Keenan (1991) & NBA players $1984-85$ & $\begin{array}{l}14-16 \% \text { premium for white players, the reported } 16 \% \\
\text { effect is significant }(5 \%) \text {. }\end{array}$ \\
\hline Bodvarsson and Brastow (1998) & NBA players 1990-91 & No evidence of salary discrimination. \\
\hline Hamilton (1997) & NBA players 1994-95 & $\begin{array}{l}\text { No average white premium; } 18 \% \text { white premium at upper } \\
\text { end of distribution. }\end{array}$ \\
\hline Dey (1997) & NBA players 1987-93 & No evidence of salary discrimination. \\
\hline Gius and Johnson (1998) & NBA players 1996-97 & No evidence of salary discrimination. \\
\hline Eschker, Perez and Siegler (2004) & NBA players $1996-2002$ & $\begin{array}{l}\text { No significant race salary differences in } 5 \text { of } 6 \text { seasons; in } \\
1998-99 \text {, significant } 14-20 \% \text { white premium. }\end{array}$ \\
\hline Kahn and Shah (2005) & NBA players 2001-02 & $\begin{array}{l}\text { No significant race differences in annual salary overall; } \\
\text { significantly longer contracts and higher total } \\
\text { contractwide compensation for whites overall; for non- } \\
\text { free agent players who are not on rookie scale contracts, } \\
\text { a significant white premium in annual salary, contract } \\
\text { duration and total contractwide compensation. }\end{array}$ \\
\hline Kahn (2006) & NBA coaches 1997-2004 & $\begin{array}{l}\text { No evidence of salary discrimination against black } \\
\text { coaches. }\end{array}$ \\
\hline Humphreys (2000) & College Coaches 1990-91 & $\begin{array}{l}\text { No significant gender salary gap, controlling for type of } \\
\text { program, performance and experience. }\end{array}$ \\
\hline
\end{tabular}




\begin{tabular}{|c|c|c|}
\hline Study & Setting & Results \\
\hline Kahn and Sherer (1988) & NBA players $1985-86$ & $\begin{array}{l}\text { No evidence of racial discrimination in player draft, } \\
\text { controlling for college performance. }\end{array}$ \\
\hline Dey (1997) & NBA players 1987-92 & $\begin{array}{l}\text { No evidence of discrimination in player draft, controlling } \\
\text { for college performance. }\end{array}$ \\
\hline Brown, Spiro, and Keenan (1991) & NBA players $1984-85$ & $\begin{array}{l}\text { Black benchwarmers generally do not perform } \\
\text { significantly better than white benchwarmers. }\end{array}$ \\
\hline Kahn (2006) & NBA coaches 1997-2003 & $\begin{array}{l}\text { No evidence of racial discrimination in discharges; also no } \\
\text { significant differences between performance of marginal } \\
\text { black and marginal white coaches. }\end{array}$ \\
\hline Hoang and Rascher (1999) & NBA players 1980-91 & $\begin{array}{l}\text { White players have } 36 \% \text { lower risk of being cut than black } \\
\text { players (significant at } 10 \% \text { ). }\end{array}$ \\
\hline Groothuis and Hill (2004) & NBA players 1989-99 & No evidence of racial exit discrimination. \\
\hline Kahn and Shah (2005) & NBA players 2001-02 & $\begin{array}{l}\text { No evidence of racial discrimination in player draft, } \\
\text { controlling for college performance. }\end{array}$ \\
\hline
\end{tabular}




\begin{tabular}{|c|c|c|}
\hline Study & Setting & Results \\
\hline Kahn and Sherer (1988) & NBA $1980-86$ & $\begin{array}{l}\text { White players significantly raise attendance by } 5700-13000 \text { per year per } \\
\text { white player. }\end{array}$ \\
\hline Brown, Spiro, and Keenan (1991) & NBA 1988 and 1983-4 & $\begin{array}{l}\text { Racial makeup of team is significantly positively related to racial } \\
\text { makeup of the area (1988); percent of time played by blacks does not } \\
\text { significantly affect attendance (1983-84). }\end{array}$ \\
\hline Burdekin and Idson (1991) & NBA $1980-86$ & $\begin{array}{l}\text { Racial makeup of team is significantly positively related to racial } \\
\text { makeup of the area; closeness of racial match between team and SMSA } \\
\text { significantly positively affects attendance. }\end{array}$ \\
\hline McCormick and Tollison (2001) & NBA $1980-88$ & $\begin{array}{l}\text { Team racial composition on average has no effect on attendance; in the } \\
25 \% \text { MSA's with highest black relative population, black players raise } \\
\text { attendance. }\end{array}$ \\
\hline Hoang and Rascher (1999) & NBA 1980-91 & $\begin{array}{l}\text { Racial makeup of team is significantly positively related to racial } \\
\text { makeup of the area. Higher values of white representation on the team } \\
\text { relative to white representation in the population raise attendance. }\end{array}$ \\
\hline Bodvarsson and Partridge (2001) & NBA $1985-86$ and $1990-91$ & $\begin{array}{l}\text { Black population share interacts positively with black team share in } \\
\text { salary determination. }\end{array}$ \\
\hline Dey (1997) & NBA 1987-93 & No significant effect of team racial composition on attendance. \\
\hline Stone and Warren (1999) & NBA trading cards 1993 & No significant racial effect on pricing of NBA trading cards. \\
\hline Kanazawa and Funk (2001) & NBA 1996-97 & White players significantly raise Nielsen television ratings. \\
\hline Burdekin, Hossfeld and Smith (2005) & NBA 1990-99 & $\begin{array}{l}\text { Racial makeup of team is significantly positively related to racial } \\
\text { makeup of the area; closeness of racial match between team and SMSA } \\
\text { significantly positively affects attendance. }\end{array}$ \\
\hline Kahn and Shah (2005) & NBA 1996-2001 & No significant effect of team racial composition on attendance. \\
\hline Coleman, DuMond and Lynch (2008) & NBA 1995-2005 & $\begin{array}{l}\text { No evidence of racial discrimination in NBA Most Valuable Player award } \\
\text { voting by writers and broadcasters. }\end{array}$ \\
\hline Brown and Jewell (1994) & $\begin{array}{l}\text { College basketball 1988- } \\
89\end{array}$ & Higher share of black players significantly lowers gate revenue. \\
\hline
\end{tabular}

